\title{
EFEKTIVITAS RIZOBAKTERI ISOLAT TANAMAN TOMAT (Lycopersicum esculentum Mill.) TERHADAP DAYA HAMBAT PERTUMBUHAN KOLONI PATOGEN Fusarium oxysporum TANAMAN TERUNG (Solanum melongena L.) SECARA IN VITRO
}

\author{
EFFECTIVENESS OF RIZOBACTERIAL TOMATO PLANT (Lycopersicum esculentum \\ Mill.) ISOLATES ON PATHOGENIC COLUMN GROWTH POWER OF Fusarium \\ oxysporum EGGPLANT (Solanum melongena L.) IN VITRO
}

\author{
Rivayani Ahyamaqvirah ${ }^{1}$, Nanda Mayani ${ }^{1}$, Syamsuddin $^{1 *}$
}

${ }^{1}$ Program Studi Peternakan, Fakultas Pertanian, Universitas Syiah Kuala

\begin{abstract}
Abstrak. Penelitian ini bertujuan untuk mendapatkan rizobakteri isolat tanaman tomat yang mampu berperan sebagai agen biokontrol dalam menghambat pertumbuhan koloni patogen Fusarium oxysporum tanaman terung secara in vitro. Penelitian ini dilaksanakan di Laboratorium Ilmu dan Teknologi Benih Jurusan Agroteknologi, Fakultas Pertanian, Universitas Syiah Kuala, Darussalam Banda Aceh dari bulan Mei sampai Juli 2018. Rancangan yang digunakan pada uji antagonisme rizobakteri dengan patogen adalah Rancangan Acak Lengkap (RAL) non faktorial. Parameter yang diamati adalah persentase penghambatan pertumbuhan koloni patogen dan laju penghambatan pertumbuhan koloni patogen. Hasil penelitian menunjukkan persentase daya hambat rizobakteri yang tertinggi dalam menghambat pertumbuhan koloni patogen yaitu isolat SRK 5/3 dengan nilai $61,97 \%$ dengan aktivitas tinggi dan laju penghambatan isolat rizobakteri yang menekan pertumbuhan koloni, hifa, dan spora yaitu isolat SRK 5/3 dengan nilai $11,50 \mathrm{~mm} / \mathrm{hari}$.
\end{abstract}

Kata kunci : Rizobakteri, Fusarium oxysporum, Agen biokontrol.

\begin{abstract}
This study aims to obtain rhizobacteria from tomato isolates which are able to act as biocontrol agents for inhibiting the growth of pathogenic colonies of Fusarium oxysporum in eggplant plants by in vitro method. This research was carried out at the Laboratory of Seed Science and Technology, Department of Agrotechnology, Faculty of Agriculture, Syiah Kuala University, Darussalam Banda Aceh, from May to July 2018. The test of rhizobacterial antagonism with pathogens used non-factorial Completely Randomized Design (CRD). The parameters of this research were the percentage of inhibition of the pathogenic colonies growth and the rate of inhibition of the pathogenic colonies growth. The results showed that the highest percentage of rhizobacterial inhibition for hampering the growth of pathogenic colonies, SRK 5/3 isolates with $61.97 \%$ values with high activity and the rate of inhibition of rhizobacterial isolates which suppressed the growth of colony, hyphae, and spores, is $5 / 3 \mathrm{SRK}$ isolates with the value of $11.50 \mathrm{~mm} /$ day.
\end{abstract}

Keywords: Rhizobacteria, Fusarium oxysporum, Agens biocontrol

\section{PENDAHULUAN}

Terung (Solanum melongena L.) merupakan tanaman jenis tanaman sayur-sayuran yang tergolong dalam famili Solanaceae. Buah terung disenangi banyak orang baik dikonsumsi dalam dalam bentuk segar mapun diolah menjadi jenis masakan lainnya (Jumini dan Marliah, 2009). Permintaan terung semakin meningkat seiring dengan bertambahnya jumlah penduduk dan meningkatnya kesadaran masyarakat serta manfaat sayur-sayuran untuk memenuhi kebutuhan gizi keluarga, sehingga produksi terung perlu terus ditingkatkan (Jumini dan Marliah, 2009). Meskipun produktivitas terung terus meningkat tiap tahunnya, namun produksi terung di Indonesia tergolong rendah yaitu menyumbang $1 \%$ dari total kebutuhan dunia (Simatupang, 2010).

Banyak faktor yang mengakibatkan rendahnya produktivitas terung di Indonesia, salah satunya yaitu mikroorganisme disekitar perakaran tanaman yang memberi dampak menguntungkan dan merugikan terhadap tanaman budidaya. Dampak menguntungkan yaitu seperti fiksasi nitrogen, mikoriza, pengendalian hayati patogen tanaman, memproduksi senyawa pemacu pertumbuhan, dan yang merugikan seperti penyakit, bakteri perusak akar, 
dan imobilitas nutrisi tanaman serta serangan penyakit tanaman. Fusarium merupakan salah satu jamur yang bersifat tular tanah atau "soil-borne pathogen" (Nurcahyanti et al., 2013).

Beberapa upaya telah dilakukan dalam mengendalikan layu fusarium belum berhasil secara maksimal karena patogen bersifat tular tanah dan dapat bertahan lama didalam tanah sekalipun tidak ada tanaman inangnya, hal ini menyebabkan rotasi tanaman menjadi kurang efektif. Pengendalian penyakit dengan mengaplikasikan fungisida sintetik kedalam tanah hanya dapat menekan penyakit layu fusarium beberapa bulan saja (Alabouvette et al., 1996).

Untuk mengatasi permasalahan tersebut secara berkesinambungan perlu dilakukan perbaikan teknik budidayanya. Salah satu upaya yang dapat dikembangkan adalah dengan memanfaatkan sumber daya alam misalnya dengan memanfaatkan kemampuan secara alami dari rizobakteri rizosfer tanaman. Pengendalian hayati merupakan perlindungan tanaman dari patogen termasuk peyebaran mikroorganisme antagonis pada saat sebelum atau setelah terjadinya infeksi patogen (Agrios, 2005). Salah satu yang mempengaruhi keanekaragaman dan struktur komunitas rizobakteri berasal dari jenis tanaman dan umur tanaman (Widyati, 2013). Diduga bahwa jenis isolat rizobakteri yang berasal dari rizosfer tanaman tomat juga dapat mengendalikan cendawan patogen tanaman terung, hal ini disebabkan karena tanaman tomat dan taman terung satu famili (solanaceae).

Hasil penelitian Kuswinanti et al. (2014) terdapat 14 isolat rizobakteri dari tanaman kentang yang bersifat antagonis terhadap $F$. oxysporum dengan persentase penghambatan mencapai 92.30\%. Rizobakteri strain Pseudomonas fluorescens dilaporkan efektif dalam mengendalikan penyakit layu fusarium pada tomat akibat serangan patogen $F$. oxysporum f.sp. lycopersici (Ramamoorthy et al., 2002), Silva et al. (2004) melaporkan Bacillus cereus efektif terhadap Alternaria solani yang menyebabkan penyakit layu pucuk dan Oidium lycopersici penyebab penyakit embun tepung pada tomat

Hasil penelitian (Syamsuddin et al., 2006;2007) Strain B. subtilis, B. coagulans, B. megaterium dan $S$. marcescen ternyata juga telah terbukti mempunyai daya penghambat yang tinggi terhadap pertumbuhan $P$. capsici cabai secara in vitro maupun in vivo. Benih cabai yang mendapat perlakuan agen biokontrol, menghasilkan pertumbuhan dan produksi tanaman di rumah kasa yang nyata lebih tinggi dan lebih resisten terhadap patogen $P$. capsici (Syamsuddin,2010).

Berdasarkan Uraian diatas maka perlu dilakukan Penelitian terkait dengan kemampuan rizobakteri sebagai agen biokontrol dalam menghambat pertumbuhan koloni patogen F. oxysporum asal tanaman terung.

\title{
METODE PENELITIAN
}

Penelitian ini dilaksanakan di Laboratorium Ilmu dan Teknologi Benih Jurusan Agroteknologi, Fakultas Pertanian, Universitas Syiah Kuala, Darussalam Banda Aceh. Pelaksanaan penelitian dimulai dari Mei sampai juli 2018.

\begin{abstract}
Alat dan bahan
Alat-alat yang digunakan dalam penelitian ini adalah Laminar air flow, incubator, vortex, autoclave, mikroskop, cork borred, jarum ose, timbangan analitik, pipet ukur, lampu bunsen, oven listrik, ruang inkubasi, kompor gas, cangkul, pisau, ayakan, saringan, alat tulis, kamera, erlenmeyer, tabung reaksi, cawan petri dan spatula. Bahan-bahan yang digunakan dalam penelitian ini adalah isolat $F$. oxysporum dan 18 isolat rizobakteri koleksi Laboratorium Ilmu dan Teknologi Benih Fakultas Pertanian Universitas Syiah Kuala, media PDA (Potato Dextrose Agar), alkohol, plastik tahan panas, aquades, karet gelang, kertas label, aluminium foil, tissu, plastik wrap, spiritus, dan sabun cuci piring.
\end{abstract}




\section{Rancangan Percobaan}

Rancangan yang digunakan pada uji antagonisme rizobakteri dengan patogen adalah Rancangan Acak Lengkap (RAL) non faktorial. Faktor yang diteliti dalam penelitian ini adalah isolat rizobakteri yang telah dilakukan pengujian awal dan diseleksi kemampuannya menghambat patogen yang akan diulang sebanyak $3 \mathrm{kali}$, isolat rizobakteri agen biokontrol diuji kemampuan antagonisnya dengan patogen $F$. oxysporum pada tanaman terung, dimana rizobakteri diberi simbol $\mathrm{R}$ dan jamur patogen diberi simbol $\mathrm{P}$.

\section{Pelaksanaan Penelitian \\ Sterilisasi Alat}

Alat-alat yang digunakan seperti erlenmeyer, tabung reaksi, cawan petri, spatula dicuci terlebih dahulu dengan menggunakan sabun cuci piring. Kemudian setelah bersih alat dikeringkan didalam oven listrik selama 15-20 menit. Setelah kering alat-alat tersebut disterilkan terlebih dahulu sebelum penelitian. Alat-alat dibungkus menggunakan kertas koran kemudian dimasukkan kedalam oven listrik. Kemudian oven listrik dihidupkan pada suhu 121 ${ }^{0} \mathrm{C}$ selama 4 jam. Alat-alat yang sudah disterilkan kemudian ditunggu hingga mencapai suhu kamar (Lay dan Hastowo, 1992).

\section{Pembuatan Media PDA (Potato Dextrose Agar)}

Kentang sebanyak $200 \mathrm{~g}$ dicuci bersih dan dikupas kulitnya. Kentang selanjutnya dipotong sekitar $1 \mathrm{~cm} \times 1 \mathrm{~cm}$ kemudian direbus dengan aquades sebanyak $500 \mathrm{ml}$ hingga mendidih dan kentang berstekstur empuk. Hal ini dapat diketahui dengan menusuk kentang, jika ditusuk terasa lunak, berarti kentang telah mengeluarkan sarinya lalu disaring ekstraknya. Aquades steril dipanaskan sebanyak $500 \mathrm{ml}$ bersama dengan agar sebanyak $15 \mathrm{~g}$ dan dextrose sebanyak 15 g, diaduk hingga kedua bahan tersebut larut, jika sudah larut dengan baik dilakukan penyaringan. Dimasukkan hasil saringan ekstrak kentang ke dalam elemeyer berukuran $1000 \mathrm{ml}$ kemudian ditutup menggunakan alumunium foil dan plastik anti panas serta diikat dengan menggunakan 4 karet gelang. Larutan PDA disterilkan didalam autoclave selama 15 menit pada suhu $121-124{ }^{\circ} \mathrm{C}$. Setelah disterilkan, biarkan larutan PDA tersebut hingga suhunya turun menjadi hangat $\left(10-20{ }^{\circ} \mathrm{C}\right)$ dan siap dituang ke dalam petridish. Disimpan larutan PDA tersebut didalam Laminar Air Flow hingga agarnya memadat dan siap digunakan (Rahmanita, 2017).

\section{Deteksi, Isolasi dan Identifikasi Patogen $F$. oxysporum}

Pendeteksian dan identifikasi patogen $F$. oxysporum dilaksanakan di laboratorium, tidak menggunakan rancangan percobaan. Diambil bagian tanaman yang terinfeksi penyakit F. oxysporum. Kemudian diisolasi dengan cara dipotong kecil-kecil sekitar $1 \mathrm{~cm}$. Bahan isolasi yang digunakan adalah potongan tanaman terung tersebut. Selanjutnya bahan isolasi direndam menggunakan hipoklorit $2 \%$ selama 5 menit sebagai desinfektan untuk mengurangi kontaminasi mikroorganisme lain. Kemudian bahan isolasi dicuci sebanyak 3 kali. Potongan dikulturkan dalam cawan petri yang berisi media PDA dan diinkubasi \pm 7 hari, dengan suhu ruang $26-29{ }^{0} \mathrm{C}$ dengan penyinaran NUV 12 jam terang dan 12 jam gelap. Koloni patogen yang telah diperoleh disubkulturkan untuk memperoleh isolat murni. Kemudian disimpan dan secara berkala dilakukan peremajaan. Identifikasi dilakukan berdasarkan pengamatan makroskopik karakter kultur (Diekmann, 1993).

\section{Pengambilan Sampel Tanah dari Daerah Rizosfer Tanaman Tomat Untuk Isolasi Rizobakteri Kandidat Agen Biokontrol}

Sampel tanah yang digunakan untuk mendapatkan rizobakteri agen biokontrol diambil pada rizosfer (perakaran) tanaman tomat pada kedalaman $0-20 \mathrm{~cm}$. Tanah diambil pada pertanaman tomat petani yaitu di desa Serulee Kayu, Tingkeum, Balcalu Simpang 3, 
Kecamatan Bukit dan Desa Hakim Wih Ilang, Kecamatan Bandar, Kabupaten Bener Meriah, Provinsi Aceh. Kelompok kandidat agen biokontrol diisolasi pada perakaran tanaman tomat sehat diantara tanaman yang sakit tanpa ada serangan patogen. Pada setiap lokasi diambil sekitar $1 \mathrm{~kg}$ tanah dan kemudian contoh tanah tersebut dicampur hingga homogen dan diberi label. Tanah contoh komposit ini dikering anginkan selama satu hari dan disaring dengan saringan 9 mesh. Selanjutnya tanah tersebut dibawa ke laboratorium untuk diisolasi.

\section{Pembuatan Media NA (Nutrient Agar)}

Pembuatan Nutrien Agar (NA) diawali dengan pencampuran 20 g NA powder dalam 1 L air aquades steril, kemudian kedua bahan induk hingga larut. Larutan campuran NA dimasukkan ke dalam erlenmeyer, kemudian ditutup dengan menggunakan plastik tahan panas dan aluminium foil kemudian diikat dengan karet hingga kedap udara. Kemudian larutan NA disterilkan selama 15 menit menggunakan autoclave dengan suhu $121{ }^{\circ} \mathrm{C}$. Setelah disterilkan, larutan NA didinginkan hingga suhunya turun menjadi hangat-hangat kuku. Kemudian larutan NA dituang kedalam cawan petri sebanyak $10 \mathrm{ml}$. Larutan kemudian disimpan di dalam Laminar Air Flow Cabinet agar tidak terjadi kontaminasi. Setelah agarrnya memadat, media siap digunakan (Liu, 2008).

\section{Isolasi Rizobakteri sebagai Agen Biokontrol}

Isolasi rizobakteri dari tanah dilakukan dengan cara pengenceran berseri. Sebelum pengenceran dilakukan disiapkan satu tabung reaksi yang berisi $10 \mathrm{ml}$ aquades stelir dan 1 gram sampel tanah, dan disebut sebagai biang. Lalu disiapkan 8 tabung reaksi yang berisi aquades steril sebanyak $9 \mathrm{ml}$ setiap tabung. Kemudian tabung reaksi yang berisi tanah yang sudah disiapkan dishaker dengan vortex hingga homogen, dari tabung reaksi tersebut diambil $1 \mathrm{~mL}$ suspensi tanah lalu dimasukkan ke dalam tabung reaksi pertama secara steril, tabung reaksi pertama yang ditambahkan $1 \mathrm{ml}$ suspensi tanah disebut sebagai pengenceran pertama $\left(10^{-1}\right)$, setelah suspensi homogen ditambahkan $1 \mathrm{ml}$ suspensi dari tabung pengenceran $10^{-1}$ menggunakan pipet ukur lalu dimasukkan ke tabung reaksi kedua secara steril yang kemudian disebut sebagai pengenceran $10^{-2}$. Pemindahan suspensi dilakukan hingga sampai pengenceran ke delapan $\left(10^{-8}\right)$. Suspensi pengenceran $10^{-3}, 10^{-4}, 10^{-5}, 10^{-6}, 10^{-7}$, dan $10^{-8}$ masing-masing ditanam dengan mengambil sebanyak $0.1 \mathrm{ml}$ suspensi dan dituang pada media NA di dalam cawan petri. Koloni dari setiap rizobakteri yang tumbuh kemudian disubkulturkan beberapa kali sehingga didapatkan isolat murni.

\section{Pengujian Awal Daya Hambat Rizobakteri Terhadap Pertumbuhan Patogen F. oxysporum}

Rizobakteri yang telah berhasil diisolasi kemudian diseleksi. Kemudian diuji potensi rizobakteri dalam menghambat pertumbuhan patogen layu fusarium, sseleksi dilakukan pada media PDA dengan meletakkan potongan patogen berukuran $0,5 \mathrm{~cm}$ ditengah cawan petri dan meletakkan 4 isolat rizobakteri berjarak $2,25 \mathrm{~cm}$ dengan isolat patogen.

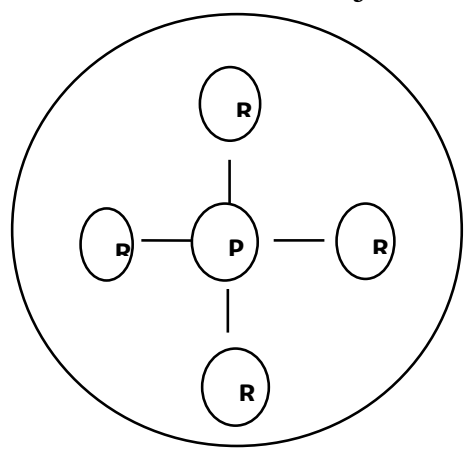

Ket : $\mathrm{R}=$ Rizobakteri $\mathrm{P}=$ Jamur Patogen

Gambar 1. Ilustrasi Seleksi Tahap Awal Daya Hambat Bakteri terhadap Patogen 
Kriteria isolat bakteri yang akan dipilih sebagai kandidat agen biokontrol adalah rizobakteri dengan koloni muncul paling awal dan ukuran koloni besar, warna dan bentuknya jelas, serta membentuk zona hambatan dengan rizobakteri dan patogen di sekitarnya. Rizobakteri yang sesuai dengan kriteria yang didapatkan kemudian diuji antagonismenya dengan cara kultur ganda.

\section{Uji Antagonis Rizobakteri Terhadap Patogen Layu Fusarium Tanaman Terung (Cara Kultur Ganda)}

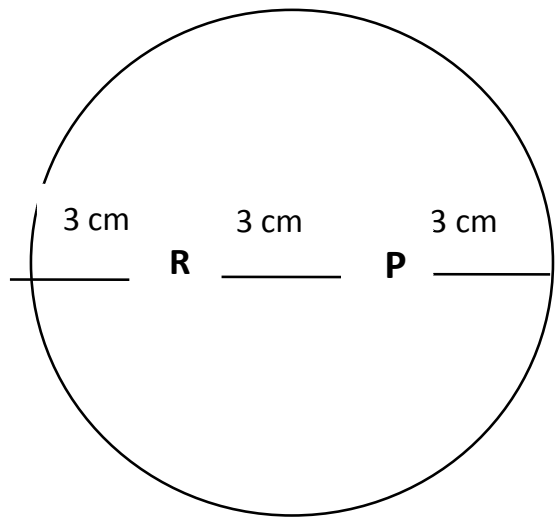

Ket : $\quad \mathrm{R}=$ Rizobakteri

$\mathrm{P}=$ Jamur Patogen

Gambar 2. Ilustrasi Uji Antagonis Rizobakteri terhadap Patogen

Rizobakteri kandidat agen biokontrol hasil isolasi yang telah diseleksi, diuji kemampuan antagonismenya melawan patogen penyebab penyakit layu fusarium menggunakan teknik kultur ganda. Kultur ganda dipersiapkan dengan cara menempatkan potongan kecil patogen (ukuran $0,5 \mathrm{~cm}$ ), dan rizobakteri antagonis yang sudah tumbuh dengan baik, koloninya sudah memenuhi petri yaitu rizobakteri umur 4 hari, pengujian dilakukan pada media PDA dalam cawan petri berdiameter $9 \mathrm{~cm}$. Titik inokulasi antara patogen dan rizobakteri antagonis berjarak $3 \mathrm{~cm}$. Pengujian diinkubasikan pada temperatur ruangan $\left(28-29{ }^{\circ} \mathrm{C}\right)$, selanjutnya diamati setiap hari hingga 7 hari.

\section{HASIL DAN PEMBAHASAN}

\section{Hasil}

\section{Peremajaan Isolat Rizobakteri}

Rizobakteri yang digunakan berasal dari rizosfer tanaman tomat, yang mana rizosfer tersebut diperoleh dari tempat yang berbeda, yaitu Hakim Wih Ilang (HWI), Balcalu Simpang 3 (BS3), Serule Kayu (SRK) dan Tingkeum (TKM), Kecamatan Bandar, Kabupaten Bener Meriah.

Isolat rizobakteri yang digunakan dipersiapkan dengan cara melakukan peremajaan pada 18 isolat rizobakteri koleksi Laboratorium Ilmu dan Teknologi Benih, Fakultas Pertanian, Universitas Syiah Kuala yang merupakan hasil isolasi oleh Tia Royanti. Peremajaan isolat rizobakteri dilakukan dengan menggunakan media PDA. Adapun isolat rizobakteri yang digunakan pada percobaan ini disajikan pada Tabel 1. 
Tabel 1. Isolat-isolat hasil isolasi dari rizosfer tanaman tomat

\begin{tabular}{cccc}
\hline $\begin{array}{c}\text { Rizobakteri Desa Hakim } \\
\text { Wih Ilang }\end{array}$ & $\begin{array}{c}\text { Rizobakteri Desa Balcalu } \\
\text { Simpang 3 }\end{array}$ & $\begin{array}{c}\text { Rizobakteri Desa Serulee } \\
\text { Kayu }\end{array}$ & $\begin{array}{c}\text { Rizobakteri Desa } \\
\text { Tingkeum }\end{array}$ \\
\hline HWI4/1 & BS34/5 & SRK5/1 & TKM4/8 \\
HWI4/2 & BS35/3 & SRK5/2 & TKM8/5 \\
HWI4/3 & BS35/4 & SRK5/3 & \\
HWI4/4 & & SRK5/4 & \\
HWI5/1 & & SRK5/5 & \\
HWI8/6 & & & \\
\hline
\end{tabular}

Ket: HWI = Hakim Wih Ilang, BS3 = Balcalu Simpang, SRK = Serulee Kayu, TKM = Tingkeum.

\section{Efektivitas Rizobakteri Isolat Tanaman Tomat Terhadap Pertumbuhan Koloni Patogen Fusarium oxysporum Tanaman Terung}

Isolat rizobakteri agen biokontrol di uji kemampuan antagonismenya dalam menghambat pertumbuhan koloni patogen $F$. oxysporum tanaman terung secara in vitro dengan teknik kultur ganda. Dari percobaan ini diperoleh hasil bahwa isolat rizobakteri dari rizosfer tomat berpengaruh tidak nyata pada persentase penghambatan pertumbuhan koloni patogen, namun berpengaruh sangat nyata terhadap laju penghambatan pertumbuhan koloni patogen.

\section{Persentase Penghambatan Pertumbuhan Koloni Patogen}

Rata-rata persentase (\%) daya hambat setiap isolat rizobakteri agen biokontrol terhadap pertumbuhan koloni patogen tanaman terung secara in vitro dapat dilihat pada Tabel 2.

Tabel 2 menunjukkan bahwa daya hambat rizobakteri agen biokontrol secara in vitro yang memiliki daya hambat terbaik terhadap pertumbuhan koloni patogen $F$. oxysporum yaitu isolat SRK5/3 dengan persentase $61,97 \%$ dan aktivitas penghambatan $+++=61-75 \% \mathrm{DH}$. Sedangkan untuk persentase penghambatan terendah terdapat pada isolat SRK5/5 dengan nilai $37,86 \%$ dan aktivitas daya hambat rendah $(+=<50 \% \mathrm{DH})$.

Tabel 2. Rata-rata persentase (\%) daya hambat isolat rizobakteri agen biokontrol terhadap pertumbuhan koloni patogen tanaman terung secara in vitro

\begin{tabular}{|c|c|c|c|}
\hline \multirow[t]{2}{*}{$\begin{array}{l}\text { Isolat rizobakteri agen } \\
\text { biokontrol }\end{array}$} & \multirow{2}{*}{$\begin{array}{c}\text { Daya hambat terhadap } \\
\text { patogen } \\
\text { F. oxysporum }(\%)\end{array}$} & \multirow{2}{*}{$\begin{array}{c}\text { Daya hambat terhadap } \\
\text { patogen } \\
\text { F. oxysporum (\%) } \\
\text { (Arcsin } \sqrt{ } \%)\end{array}$} & $\begin{array}{l}\text { Aktivitas daya hambat } \\
\text { terhadap }\end{array}$ \\
\hline & & & $\begin{array}{l}\text { Patogen } \\
\text { oxysporum }(\%)\end{array}$ \\
\hline HWI4/1 & 52,23 & 46,65 & + \\
\hline HWI4/2 & 38,87 & 38,50 & + \\
\hline HWI4/3 & 41,11 & 39,88 & + \\
\hline HWI4/4 & 44,44 & 41,81 & + \\
\hline HWI5/1 & 48,89 & 44,36 & + \\
\hline HWI5/4 & 53,30 & 47,01 & + \\
\hline HWI8/6 & 51,13 & 45,66 & + \\
\hline BS34/5 & 48,87 & 44,34 & + \\
\hline $\mathrm{BS} 35 / 1$ & 38,89 & 38,51 & + \\
\hline $\mathrm{BS} 35 / 3$ & 42,20 & 40,46 & + \\
\hline BS35/4 & 50,00 & 45,00 & + \\
\hline SRK5/1 & 52,20 & 46,26 & + \\
\hline SRK5/2 & 48,89 & 44,35 & + \\
\hline SRK5/3 & 63,32 & 61,97 & +++ \\
\hline SRK5/4 & 52,22 & 46,26 & + \\
\hline SRK5/5 & 37,78 & 37,86 & + \\
\hline TKM4/8 & 51,11 & 45,64 & + \\
\hline TKM8/5 & 52,22 & 46,37 & + \\
\hline
\end{tabular}


Keterangan: aktivitas sangat tinggi $(++++=>75 \% \mathrm{DH})$, aktivitas tinggi $(+++=61-75 \% \mathrm{DH})$, aktivitas sedang $(++=51-60 \% \mathrm{DH})$, aktivitas rendah $(+=<50 \% \mathrm{DH})$ dan tidak ada aktivitas $(-)$

\section{Laju Penghambatan Pertumbuhan Koloni Patogen}

Rata-rata laju penghambatan koloni patogen $F$. oxysporum pada setiap isolat rizobakteri dapat dilihat pada Tabel 3.

Tabel 3. Laju Penghambatan Isolat Rizobakteri Kandidat Agen Biokontrol Terhadap Pertumbuhan Koloni Patogen F. oxysporum

\begin{tabular}{lc}
\hline Rizobakteri Agen Biokontrol & $\begin{array}{c}\text { Laju penghambat Terhadap Patogen } \\
\text { F. oxysporum }(\mathrm{mm} / \mathrm{hari})\end{array}$ \\
HWI4/1 & $19,50 \mathrm{de}$ \\
HWI4/2 & $19,50 \mathrm{de}$ \\
HWI4/3 & $18,82 \mathrm{c}-\mathrm{e}$ \\
HWI5/4 & $17,40 \mathrm{~b}-\mathrm{e}$ \\
HWI5/4 & $14,25 \mathrm{a}-\mathrm{c}$ \\
HWI8/6 & $13,33 \mathrm{ab}$ \\
BS34/5 & $17,97 \mathrm{~b}-\mathrm{e}$ \\
BS35/1 & $14,25 \mathrm{a}-\mathrm{c}$ \\
BS35/3 & $13,97 \mathrm{de}$ \\
BS35/4 & $18,87 \mathrm{c}-\mathrm{e}$ \\
SRK5/1 & $17,42 \mathrm{~b}-\mathrm{e}$ \\
SRK5/2 & $15,72 \mathrm{a}-\mathrm{e}$ \\
SRK5/3 & $18,25 \mathrm{~b}-\mathrm{e}$ \\
SRK5/4 & $11,50 \mathrm{a}$ \\
SRK5/5 & $17,27 \mathrm{~b}-\mathrm{e}$ \\
TKM4/8 & $20,62 \mathrm{e}$ \\
BNM $/ 5$ & $17,03 \mathrm{~b}-\mathrm{e}$ \\
Angka yang diikuti oleh huruf yang sama pada kolom yang sama berbeda tidak nyata pada Uji & 15,50 a-d \\
Beda Nyata Jujur (BNJ) pada taraf $\alpha=5 \%$ & 2,94 \\
\hline Keterangan:
\end{tabular}

Tabel 3 menunjukkan bahwa laju penghambatan tertinggi terdapat pada isolat SRK5/5 dengan nilai laju pernghambatan sebesar 20,62 $\mathrm{mm} /$ hari yang berbeda tidak nyata dengan 11 isolat lainnya, tetapi berbeda nyata dengan 6 isolat yaitu HWI5/1, HWI5/4, BS34/5, BS34/5, SRK5/3, SRK5/5 dan TKM8/5. Sedangkan untuk laju penghambatan terendah terdapat pada isolat SRK5/3 yaitu $11,50 \mathrm{~mm} / \mathrm{hari}$.

\section{Pembahasan}

Hasil pengujian 18 isolat rizobakteri agen biokontrol terhadap kemampuannya dalam menghambat pertumbuhan koloni patogen $F$. oxysporum tanaman terung secara in vitro diperoleh hasil bahwa isolat rizobakteri berpengaruh tidak nyata pada persentase penghambatan pertumbuhan koloni patogen $F$. oxysporum. Hasil uji antagonis menunjukkan persentase penghambatan yang tertinggi dalam menekan pertumbuhan koloni patogen yaitu isolat SRK5/3 sebesar $61,97 \%$, sedangkan pada laju penghambatan pertumbuhan koloni patogen isolat rizobakteri berpengaruh sangat nyata dengan laju penghambatan terbaik yang mampu menghambat pertumbuhan koloni, spora dan hifa yaitu isolat SRK5/3 dengan nilai $11,50 \mathrm{~mm} / \mathrm{hari}$.

Berdasarkan hasil Penelitian Sutariati (2006) uji daya hambat isolat rizobakteri terhadap pertumbuhan koloni $C$. capsici, didapatkan hasil isolat Serratia sp. Tidak bersifat antagonis terhadap patogen $C$. capsici dengan daya hambat $=0 \%$, berbeda dengan isolat Pseudomonas sp. dan Bacillus sp. yang bersifat antagonis. Perbedaan ini menunjukkan bahwa kemampuan rizobakteri dalam mensintesis enzim ekstraseluler bukan satu-satunya penentu keefektifan daya hambat rizobakteri. Sebagian isolat rizobakteri yang tidak menghasilkan 
enzim ekstra-seluler ternyata mampu menekan pertumbuhan koloni patogen $C$. capsici, sedangkan isolat yang menghasilkan enzim ekstraseluler tidak memiliki daya hambat terhadap koloni patogen. Hal ini menunjukkan bahwa setiap rizobakteri memiliki kemampuan yang berbeda-beda dalam menghasilkan senyawa metabolit sekunder yang bersifat antagonis terhadap patogen (Rosadiah, 2015).

Sutariati (2010) menyatakan bahwa perbedaan keefektifan penghambatan rizobakteri diduga karena adanya perbedaan mekanisme kerja dari senyawa antimikroba yang dihasilkan oleh rizobakteri, senyawa antimikroba yang dihasilkan oleh kelompok P. fluorescens antara lain pioluteorin, pirolnitrin, fenazines, dan fusarisidin (Beatty dan Susan 2002) dan dari kelompok Bacillus spp. Menghasilkan mikosubtilins, basilomisin, fengimisin, mikobasilin, dan mikoserein (Hornby 1993), sedangkan dari kelompok Serratia spp. antara lain macrocyclic lactone A21-4 (Shen et al., 2007).

Berdasarkan hasil penelitian Safriani (2016) pengujian antagonis menggunakan metode uji kultur ganda secara in vitro, diperoleh sejumlah rizobakteri sebagai kandidat agen biokontrol yang memiliki kemampuan berbeda-beda tergantung pada jenis isolatnya. dalam mengPerbedaan kemampuan tersebut diduga memiliki kaitan erat dengan kemampuan isolat dalam mensekresikan berbagai senyawa metabolit sekunder yang bersifat antimikrob, seperti antibiotik, hidrogen sianida $(\mathrm{HCN})$ dan sintesis berbagai enzim yang mendegradasi dinding sel misalnya kitinase, selulase, lipase, dan protease (Syamsuddin et al., 2007). Selain memproduksi enzim ekstraseler, kemampuan rizobakteri dalam menghambat cendawan patogen juga dipengaruhi oleh juga dipengaruhi oleh kemampuan memproduksi siderofor, yaitu suatu mekanisme yang berperan dalam menghambat pertumbuhan koloni cendawan patogen (Cantelan et al., 1999; Luz, 2001).

Laju penghambatan isolat terbaik yaitu yang mampu menghambat pembentukan spora patogen sehingga menyebabkan jumlah spora, koloni dan hifa patogen semakin rendah. Hal ini diduga diakibatkan Terhambatnya pembentukan spora dan hifa diduga karena rizobakteri mampu menghambat sintesi protein dari cendawan patogen sehingga pertumbuhan cendawan terganggu (Wang et al., 2005).

Kemampuan laju penghambatan yang baik secara in vitro menunjukkan bahwa isolat rizobakteri tersebut bersifat antagonis yang kuat terhadap koloni cendawan patogen. Sifat antagonis tersebut diduga berkaitan erat dengan kemampuan isolat dalam mensintesis berbagai enzim ekstraseluler seperti kitinase dan selulase. Kitinase dapat mendegredasi kitin yang merupakan penyusun dari dinding sel cendawan patogen, misalnya $F$. oxysporum, $R$. solani dan $S$. rolfsii, dan selulase dapat mendegradasi selulosa yang merupakan salah satu komponen utama penyusun dinding sel dari P. capsici (Raaijmaker et al., 2008).

Holetz et al. (2002) menyatakan, kitinase dapat manfaatkan sebagai agen biokontrol terhadap jamur patogen karena mampu mengurai kitin yang merupakan komponen penyusun utama dinding sel dari jamur patogen. Berbagai organisme menghasilkan jenis kitinase yang beragam dengan spesifikasi terhadap substrat yang bervariasi, dan karakteristik yang berbeda-beda. Bakteri memproduksi kitinase sebagai sarana untuk nutrisi dan agen biokontrol (Toharisman, 2007).

Syamsuddin (2009) menyatakan bahwa rizobakteri yang mempunyai daya hambat rendah dan bahkan tidak memiliki daya hambat sama sekali dalam menekan koloni cendawan patogen $P$. capsici masih berpeluang untuk dimanfaatkan sebagai rizobakteri pemacu pertumbuhan Tanaman (RPPT). Kelompok rizobakteri ini berpeluang memiliki berbagai kemampuan lainnya seperti menghasilkan senyawa IAA, senyawa siderofor, kemampuan melarutkan fosfat dan mereduksi mangan. 


\section{KESIMPULAN DAN SARAN}

Rizobakteri isolat tanaman tomat yang berperan sebagai agen biokontrol berpengaruh tidak nyata pada persentase pertumbuhan koloni patogen $F$. oxysporum. Isolat rizobakteri dengan dengan persentase penghambatan tertinggi menghambat patogen $F$. oxysporum yaitu SRK5/3 dengan nilai persentase penghambatan sebesar $61,97 \%$. Rizobakteri isolat tanaman tomat berpengaruh sangat nyata terhadap laju penghambatan pertumbuhan koloni patogen $F$. oxysporum, dengan laju penghambatan terbaik terdapat pada isolate SRK 5/3 yang mampu menghambat pembentukan koloni, spora dan hifa dengan nilai laju pemhambat rizobakteri yaitu $11,50 \mathrm{~mm} / \mathrm{hari}$.

\section{DAFTAR PUSTAKA}

Agrios, G. N. 2005. Plant Pathology 5th ed. Academic Press, New York.

Alabouvette C, Lemanceau P \& Steinberg C. 1996. Biological control of Fusarium wilts: Opportunities for Developing a Commercial Product. Pp. 192-212. In: Hall R. Principles and Practice of Managing Soilborne Plant Pathogens. APS Press, St. Paul, Minnesota.

Beatty, P. H., dan E. J. Susan. 2002. Paenibacillus polymyxa produces fusaricidin-type antifungal antibiotics active against leptosphaeria maculans, the causative agent of blackleg disease of canola. Can. Microbiol. 4(8):159-169.

Cattelan AJ, Hartel PG \& Fuhrmann JJ. 1999. Screening for plant growth-promoting rhizobacteria to promote early soybean growth. Soil Sci. Soc. Am. J. 63: 1670-1680.

Diekmann, M. 1993. Seedborne Diseases in Seed Production. International Center for Agricultural Research in the Dry Areas (ICARDA). Aleppo, Syria.

Holetz, F.B.H., Pessini, G.L., Sanches, N.R., Cortez, D.A.G., Nakamura, C.V., and Filho, B.P.D., 2002, Screening of some plants used in the Brazilian folk medicine for the treatment of infectious diseases, Mem. Inst. Oswaldo Cruz, Rio de Janeiro. 97. 1-5.

Hornby, D. 1993. Biological Control of Soil-borne Plant Pathogens. Wallingford, UK: CAB International.

Jumini dan A. Marliah. 2009. Pertumbuhan dan hasil tanaman terung akibat pemberian pupuk daun gandasil d dan zat pengatur tumbuh harmonik. Jurnal Floratek. 4: 73-80.

Kuswinanti, T. Baharuddin dan S. Sukmawati. 2014. Efektivitas Isolat Bakteri dari Rizosfer dan Bahan Organik Terhadap Ralstonia solanacearum dan Fusarium oxysporum pada Tanaman Kentang. Jurnal Fitopatol Indones. 10, 2: 68-72.

Lay, B. W. and Hastowo. 1992. Mikrobiologi. Rajawali Press. Jakarta.

Liu, Shijun. 2008. All about agar. http:/ www. Sciencebuddies.org/ science-fairprojects/project_ideas/MicroBio_Agar.shtml. [19 Maret 2018]

Luz WC. Da. 2001. Evaluation of plant growingpromoting and bioprotecting rhizobacteria on wheat crop. Fitopathologia Brasileira 26: 597-600.

Nurcahyanti, S.D, T. Arwanto, D. Indradewa, J. Widada. 2013. Isolasi dan seleksi pseudomonad fluorescens pada risosfer penyambungan tomat. Berkala Ilmiah Pertanian. 1 (1): 15-18 
Raaijmaker JM, Paulitz TC \& Steinberg C. 2008. The rhizosphere: a playground and battlefield for soilborn pathogens and beneficial 1 microorganism. Plant Soil 10: 10071014.

Rahmanita, D. 2017. Pengaruh jenis dan kerapatan inokulum rizobakteri pemacu pertumbuhan tanaman (RPPT) terhadap viabilitas dan vigor benih cabai merah (Capsicum annum L.) kadaluarsa. Skripsi. Fakultas Pertanian Universitas Syiah Kuala, Banda Aceh.

Ramamoorthy V, Raguchander T, Samiyappan R. 2002. Induction of defenserelated proteins in tomato roots treated with Pseudomonas fluorescens Pf1 and Fusarium oxysporum f.sp.lycopersici. Plant Soil 239: 55-68.

Rosadiah, F. N., S. Ilyas dan D. Manohara. 2015. Perlakuan benih cabai (Capsicum annuum L.) dengan rizobakteri secara tunggal atau kombinasi dapat mengendalikan Phytophthora capsici dan meningkatkan pertumbuhan tanaman. Jurnal Hortikultura. Indonesia 6(1): 1-10.

Safriani. 2016. Daya hambat rizobakteri terhadap pertumbuhan koloni patogen terbawa benih cabai merah secara in vitrodan pengaruhnya terhadap viabilitas benih. Jurnal Kawista. 1(1): 50-58.

Shen, S.S., J.W. Kim., dan C.S. Park. 2002. Serratia plymuthica Strain A21-4: a potential biocontrol agenst against Phytophthora capsici of peper. Plant Pathology jurnal. 18(3): 138-141.

Silva, H.A.S., Romeiro, R.S.R., Macagnan, D., Vieira, B.A.H., Pereira, M.C.B., Mounteer, A. 2004. Rhizobacterial Induction of Systemic Resistance in Tomato plants Non Spesific Protection and Increase in Enzyme Activities. Bio Control 29:288-295.

Simatupang, A. 2010. Pengaruh beberapa jenis pupuk organik terhadap pertumbuhan dan hasil tanaman terung (Solanum melongena L.). Skripsi. Fakultas Pertanian Universitas Andalas. Padang.

Sutariati, G. A. K dan A. Wahab. 2010. Isolasi dan uji kemampuan rizobakteri indigenous sebagai agensia pengendali hayati penyakit pada tanaman cabai. Jurnal hortikultura. 20 (1). 86-95.

Sutariati, G.A.K. 2006. Perlakuan benih dengan agens biokontrol untuk pengendalian penyakit antraknosa dan peningkatan hasil serta mutu benih cabai. [Disertasi]. Sekolah Pascasarjana, Institut Pertanian Bogor, Bogor. p.163

Syamsuddin, S., Ilyas., Alfizar., dan B. Amin. 2007. Pengembangan Biological Seed Treatment untuk Pengendalian Busuk Phytophthora pada Cabai Merah (Capsicum annuum L.). Hibah Bersaing XIV Perguruan Tinggi.

Syamsuddin. 2010. Perlakuan benih untuk pengendalian penyakit busuk phytophthora, peningkatan hasil dan mutu benih cabai merah (Capsicum annuиm L). Disertasi. Sekolah Pascasarjana Institut Pertanian Bogor. Bogor. 201.

Syamsuddin. 2009. Perlakuan benih secara hayati untuk pengendalian busuk Phytophthora (Phytophthora capsici Leonian) dan peningkatan hasil serta mutu benih cabai merah (Capsicum annuum L.). Penelitian Disertasi Program Doktor di IPB. Bogor.

Toharisman, A. 2007. Peluang Pemanfaatan Enzim Kitinase di Industri Gula. Pusat Pengembangan Penelitian Geologi Kelautan (P3GL).

Widyati E, 2013. Dinamika Komunitas Mikroba Di Rizosfer Dan Kontribusinya Terhadap Pertumbuhan Tanaman Hutan. Tekno Hutan Tanaman. 6(2): 55-64.

Wang, S., J. Wu, P. Rao, \& X. Ye. 2005. A chitinase with antifungal activity from the mung bean. Protein Expr. Purif. 40:232-236. 